12. Koshelev LA. O polovom dimorfizme lopatok [On sexual dimorphism of the blades]. Sudebno-meditsinskaya ekspertiza [Forensic medical examination]. 1971; 4: 22-23.

13. Laptev ZL. Opredelenie pola i dliny tela po parametram lopatok [Determination of sex and body length by the parameters of the blades]. Sudebno-meditsinskaya ekspertiza [Forensic medical examination]. 1978; 3: 7-11.

14. Gurova NI. Vozrastnaya morfologiya grudnoy kletki cheloveka [Age morphology of the human thorax]. Moskva: «Prosveshchenie» [Moscow: «Enlightenment»]. 1965; 216 p.

\title{
NEW APPROACHES TO PREVENT AND TREAT INCRESED SERUM LIPIDS
}

SHAH MURAD, MBBS, M. Phil, professor, the Head of the Department of pharmacology of Islamabad Medical \& Dental College and Dr. Akbar Niazi Teaching Hospital, Wadi-ul-IIm Main Murree Road, Bharakahu, Islamabad, Pakistan, tel. +92-314-224-34-15, e-mail: shahhmurad@gmail.com

MASTOI ISHAQ M., PRO, Pakistan Agricultural Research Council, Park Road, Pakistan, 44000, Islamabad

ARAIN ABDUL QUDOOS, associate professor of Pharmacology at HBS Medical College, Lehtarar Road, Pakistan, Islamabad SHAFIQUE ADNAN, Cl pharmacist at MCC Pharmacy, Pakistan, Islamabad

ASLAM HINA, associate professor, Pharmacology, Islamabad Medical \& Dental College and Dr. Akbar Niazi Teaching Hospital, Wadi-ul-IIm Main Murree Road, Bharakahu, Pakistan, Islamabad

NIAZI AKBAR KHAN, MBBS, venerologist, the Chairman of Islamabad Medical \& Dental College and Dr. Akbar Niazi Teaching Hospital, Islamabad, Pakistan, Wadi-ul-IIm Main Murree Road, Bharakahu, Islamabad, tel. +92-314-224-34-15

\begin{abstract}
Inflammation triggered by oxidative stress is the cause of much, perhaps even most, chronic human disease including human aging. The oxidative stress originates mainly in mitochondria from reactive oxygen and reactive nitrogen species (ROS/RNS) and can be identified in most of the key steps in the pathophysiology of atherosclerosis and the consequential clinical manifestations of cardiovascular disease. In addition to the formation of atherosclerosis, it involves lipid metabolism, plaque rupture, thrombosis, myocardial injury, apoptosis, fibrosis and failure. The recognition of the critical importance of oxidative stress has led to the enthusiastic use of antioxidants in the treatment and prevention of heart disease, but the results of prospective, randomized clinical trials have been overall disappointing. Conventional hypolipidemic drugs have unwanted effects. Herbal therapy for Hyperlipidemia is getting attention due to their less frequent side effects. Aim. In this study we have compared hypolipidemic effects of Fenofibrate $40 \mathrm{mg}$ with Nigella sativa. Material and methods. Seventy five hyperlipidemic patients from National Hospital Lahore were enrolled for study. After getting consent all patients were divided in three groups comprising 25 patients in each group. Group 1 was on Nigella sativa, group 2 was on Gemfibrozil and third group was on placebo therapy. They were advised to take drugs for two months. After completion of study pretreatment and post treatment values of low density lipoproteins cholesterol were analyzed statistically. Results and discussion. In Nigella sativa group low density lipoproteins cholesterol decreased from $(191,14 \pm 3,45) \mathrm{mg} /$ $\mathrm{dl}$ to $(159,40 \pm 2,98) \mathrm{mg} / \mathrm{dl}$, means $31,7 \mathrm{mg} / \mathrm{dl}$ low density lipoproteins reduction was observed when compared with placebo group. In Fenofibrate group of patients' low density lipoproteins cholesterol decreased from $(197,77 \pm 3,91) \mathrm{mg} / \mathrm{dl}$ to $(159,62 \pm 2,20) \mathrm{mg} / \mathrm{dl}$, means low density lipoproteins reduction in mean values was $38,2 \mathrm{mg} / \mathrm{dl}$, when compared with placebo group. These changes are highly significant with $p$-values of $<0,001$. Conclusion. We concluded from this study that herbal medicine Nigella sativa is as effective as traditionally used hypolipidemic drug Fenofibrate.
\end{abstract}

Key words: oxidative stress, fibrates, serum lipids, Nigella sativa.

For reference: Shah M, Mastoi IM, Arain AQ, Shafique A, Aslam H, Niazi AKh. New approaches to prevent and treat increased serum lipids. The Bulletin of Contemporary Clinical Medicine. 2019; 12 (3): 56-59. DOI: 10.20969/ VSKM.2019.12(3).56-59.

(๑ М. Шах, И.М. Мастои, А.К. Араин, А. Шафик, Х. Аслам, А.Х. Ниази, 2019

\section{НОВЫЕ ПОДХОДЫ К ПРОФИЛАКТИКЕ И КОРРЕКЦИИ ГИПЕРЛИПИДЕМИИ}

ШАХ МУРАД, бакалавр медицины и бакалавр хирургии, мастер философии, профессор, зав. кафедрой фармакологии Медицинского и стоматологического колледжа в Исламабаде и Университетской клиники доктора Акбара Ниязи, Пакистан, Исламабад, Вади-уль-Ильм главная улица Мурее, Бхаракаху, тел. +92-314-224-34-15, e-mail: shahhmurad65@gmail.com

МАСтОИ ИШАК М., исследователь, Пакистанский исследовательский совет в области сельского хозяйства, Пакистан, 44000, Исламабад, Парк-роуд

АРАИн АБдул кудоОс, доцент кафедры фармакологии Медицинского колледжа НВS, Пакистан, Исламабад, Лехтрар-роуд

ШАФИК АДНАН, фармацевт I категории в аптеке МСС, Пакистан, Исламабад

АСЛАМ ХИНА, доцент кафедры фармакологии Медицинского и стоматологического колледжа в Исламабаде и Университетской клиники доктора Акбара Ниязи, Пакистан, Исламабад, Вади-уль-Илй Главная улица Мурее, Бхаракаху

НИАЗИ АКБАР-ХАН, бакалавр медицины и бакалавр хирургии, председатель Медицинского и стоматологического колледжа в Исламабаде и Университетской клиники доктора Акбара Ниязи, Пакистан, Исламабад, Вади-уль-Ильм главная улица Мурее, Бхаракаху, тел. + 92-314-224-34-15

Реферат. Воспаление, обусловленное окислительным стрессом, лежит в основе многих хронических заболеваний человека, включая процесс старения. Окислительный стресс возникает главным образом в митохондриях при участии реактивного кислорода и реактивных видов азота (ROS/RNS) и может наблюдаться при атеросклерозе 
и сердечно-сосудистых заболеваниях. В дополнение к образованию атеросклероза он оказывает влияние на липидный обмен, разрыв бляшек, тромбоз, травму миокарда, апоптоз, фиброз и сердечную недостаточность. Признание критическим важность окислительного стресса вызвало интерес к использованию антиоксидантов в лечении и профилактике заболеваний сердца, но результаты рандомизированных клинических исследований разочаровали. Общепринятые гиполипидемические препараты оказывают нежелательные эффеекты. Фитотерапия при гиперлипидемии заслуживает особого внимания из-за меньшей частоты возникновения побочных эффектов. Цель - сравнить гиполипидемические эффеекты фенофибрата (40 мг) и черного тмина (Nigella sativa). Mamepuaл и методы. 75 пациентов с гиперлипидемией, госпитализированных в Государственную больницу Лахора, были включены в исследование. После получения согласия все пациенты были разделены на 3 группы, состоящие из 25 человек каждая. Группа 1 получала черный тмин, группа 2 - гемфиброзил, группа 3 - плацебо. Пациентам было рекомендовано принимать препараты в течение 2 мес. По завершении исследования была проведена предварительная статистическая обработка результатов и оценка значений липопротеинов низкой плотности после лечения. Результаты и их обсуждение. В группе, принимавшей черный тмин, уровень липопротеинов низкой плотности снизился с $(191,14 \pm 3,45)$ мг/дл до $(159,40 \pm 2,98)$ мг/дл, со средним снижением на 31,7 мг/дл по сравнению с группой, получавшей плацебо. В группе, получавшей фенофибрат, уровень липопротеинов низкой плотности снизился с $(197,77 \pm 3,91)$ мг/дл до $(159,62 \pm 2,20)$ мг/дл. Среднее снижение липопротеинов низкой плотности составило 38,2 мг/дл по сравнению с группой, получавшей плацебо. Данные изменения имели высокую статистическую значимость ( $p<0,001)$. Выводы. Основываясь на результатах данного исследования, мы пришли к выводу, что фитотерапия препаратами черного тмина так же эффективна, как и традиционно используемый гиполипидемический препарат фенофибрат.

Ключевые слова: окислительный стресс, фибраты, липиды сыворотки, черный тмин.

Для ссылки: Новые подходы к профилактике и коррекции гиперлипидемии / М. Шах, И.М. Мастои, А.К. Араин [и др.] // Вестник современной клинической медицины. - 2019. - Т. 12, Вып. 3. - C.56-59. DOI: 10.20969/ VSKM.2019.12(3).56-59.

ntroduction. While the importance of inflammation

in illnesses where the phenomenon is overt, such as following trauma or infection has been recognized since ancient times, its presence and crucial role in the manifestation of many diseases never previously recognized as inflammatory is relatively recent. In such instances, the source of the inflammation is also often imperceptible. This is especially relevant to the many pervasive chronic diseases that are still responsible for so much human suffering [1]. We are currently achieving a major understanding of what is involved in the initiation of the inflammatory signaling cascade as well as the complex signaling pathways themselves that transcribe and counterregulate the molecular messengers that generate the biological combatants such as the inflammatory enzymes associated with the numerous relevant pathologies [2]. Oxidative stress, ROS (reactive oxygen species), hyperlipidemia, hypertension, and hyperglycemia cause syndrome like disease well known as coronary artery disease (CAD) [3]. In this syndrome atherosclerotic plaques are formed which may totally block the blood supply to the myocytes, causing cardiac attack [4]. Atherosclerotic plaque contains calcium, cholesterol, free fatty acids, and macrophages in variable amount. These plaques are of two types ie; hard and soft. Soft plaques are more vulnerable than hard and can rupture easily as compared to hard one. If a blood vessel to the brain is blocked, usually from a blood clot, an ischemic stroke cans result [5]. Hypolipidemic drugs can be used to prevent hyperlidemia, CAD, heart arrhythmias and cardiac arrest. Allopathic drugs used to prevent or cure Hyperlipidemia include Statins, Fibrates, niacin and bile acid binding resins [6]. Fenofibrate increases plasma HDL levels by stimulating their synthesis. Increased transport (turnover) of HDL induced by fenofibrate may be significant in increasing tissue cholesterol removal in hyperlipidemic patients [7]. Furthermore Fibrates treatment results in the formation of LDL with a higher affinity for the LDL receptor, which are thus catabolized more rapidly [8]. Nigella sativa or kalonji contains conjugated linoleic acid, thymoquinone, melanthin, nigilline,damascenine, and trans-anethole. Thymoquinone (TQ) extracted from Nigella sativa (kalonji) inhibits iron-dependent microsomal lipid peroxidation. Stimulation of polymorphonuclear leukocytes with thymoquinone works as protector against damaging effects of free redicles generated biochemically in human body $[9,10]$. Nigella sativa is useful to treat, inflammation, high plasma lipids, high blood pressure, asthma, diabetes mellitus [11-14].

Patients \& method. This research was single blind placebo-controlled, and was conducted at National Hospital, Lahore from February 2018 to July 2018. Seventy five hyperlipidemic patients were selected for research work. Written consent was taken from all patients. Specific Performa was designed for the research work. Seventy five newly diagnosed primary hyperlipidemic patients were selected with age range from 18 to 70 years. Exclusion criteria were hypothyroidism, diabetes mellitus, alcohol addictive patients, peptic ulcer, any gastrointestinal upset, renal impairment, and any hepatic or cardiac problem. All patients were divided in three groups (group-A, group-B, group-C), 25 in each group. Their baseline experimental data was taken and filed in specifically designed Performa, at start of taking medicine, like lipid profile, blood pressure and pulse rate. The study period was eight weeks. Twenty five patients of group-A were advised to take one tea spoon of Nigella sativa, twice daily, i.e.; one tea spoon after breakfast and one tea spoon after dinner. Twenty five patients of group-B were advised to take Fenofibrate $40 \mathrm{mg}$ tablets, one after breakfast and one after dinner. Twenty five patients were provided placebo capsules, (containing grinded wheat), taking one capsule after breakfast and another before going to bed. All participants were advised to take these medicines for eight weeks. They were also advised for 20 minutes brisk walk at morning or evening time. Patients were called every 2 weeks for follow up to check blood pressure, weight, pulse rate and general 
appearance of the individual. Drug compliance to the regimen was monitored by interview and counseling at each clinical visits. Serum LDL-cholesterol was calculated by Friedwald formula [7] (LDL-Cholesterol = Total Cholesterol-(Triglycerides/5 +HDL-Cholesterol). Data were expressed as the mean $\pm S D$ and «t» test was applied to determine statistical significance as the difference. A probability value of $<0,05$ was considered as non-significancant and $p<0,001$ was considered as highly sign

Results. When results were compiled and statistically analyzed, it was observed that Nigella sativa and Fenofibrate $40 \mathrm{mg}$ decreased LDL-cholesterol significantly. Nigella sativa decreased LDL cholesterol from $(191,14 \pm 3,45) \mathrm{mg} / \mathrm{dl}$ to $(159,40 \pm 2,98) \mathrm{mg} / \mathrm{dl}$. This change in mean values was $31,7 \mathrm{mg} / \mathrm{dl}$ with highly significant $p$-value of $<0,001$. Fenofibrate decreased LDL cholesterol from $(197,77 \pm 3,91) \mathrm{mg} / \mathrm{dl}$ to $(159,62 \pm 2,20) \mathrm{mg} / \mathrm{dl}$. In mean values this change was $38,2 \mathrm{mg} / \mathrm{dl}$ with highly significant $\mathrm{p}$-value of $<0,001$. Placebo group showed LDL cholesterol reduction from $(163,10 \pm 1,45) \mathrm{mg} / \mathrm{dl}$ to $(159,40 \pm 1,77) \mathrm{mg} / \mathrm{dl}$. This change in mean values was $3,7 \mathrm{mg} / \mathrm{dl}$, with nonsignificant $p$-value of $>0,05$ (table).

Discussion. Human body is continuously exposed to different types of agents that results in the production of reactive species called as free radicals (ROS/RNS) which by the transfer of their free unpaired electron causes the oxidation of cellular machinery. In order to encounter the deleterious effects of such species, body has got endogenous antioxidant systems or it obtains exogenous antioxidants from diet that neutralizes such species and keeps the homeostasis of body. Any imbalance between the RS and antioxidants leads to produce a condition known as «oxidative stress» that results in the development of pathological condition among which one is diabetes. Most of the studies reveal the inference of oxidative stress in diabetes pathogenesis by the alteration in enzymatic systems, lipid peroxidation, impaired Glutathione metabolism and decreased Vitamin C levels. Lipids, proteins, DNA damage, Glutathione, catalane and superoxide dismutase are various biomarkers of oxidative stress in diabetes mellitus. Oxidative stress induced complications of diabetes may include stroke, neuropathy, retinopathy and nephropathy. In allopathy hypolipidemic drugs include Statins, Fibrates, Niacin, and Bile acid binding resins. These drugs have low patient and doctor compliance due to their side effects. So herbal medicine is going to be popular even in western world. Nigella sativa is one of those medicinal herbs which is used in more than 100 diseases all over the world. In this study we have compared LDL cholesterol lowering effects of traditional drug
Fenofibrate with medicinal herb Nigella sativa. Nigella sativa when used by 25 hyperlipidemic patients for two months, it reduced LDL cholesterol 31,7 mg/dl. Statistically this change is highly significant. Our results match with results of study conducted by Summat BS et al. [15], who proved $28,99 \mathrm{mg} / \mathrm{dl}$ reduction in LDL cholesterol in 45 hyperlipidemic patients. Their results support our study results. Change in LDL cholesterol in our results are in contrast with results of study conducted by Malaq FG et al. [16], who proved much less reduction in LDL cholesterol when Nigella sativa was used in 100 hyperlipidemic patients for one month. Reason for this contrast may be due to their large sample size and less exposure of patients to take Nigella sativa for only four weeks. They have also explained mechanism of action of Nigella sativa that how these agents act as antioxidant. Nigella Sativa oil with its potent free radical scavenging properties, inhibits subarachnoidhaemorrhage-(SAH-) induced lipid peroxidation of the brain tissue against the reactive hydroxyl, peroxyl, and superoxide radicals. This mechanism is also quoted by JH Gurfatv et al. [17]. In our study fenofibrate decreased LDL cholesterol $38,2 \mathrm{mg} / \mathrm{dl}$ which is highly significant change when analyzed statistically. These results match with results of study conducted by Sangatt $U$ et al. [18], who observed LDL reduction by $40 \mathrm{mg}$ of Fenofibrate used by 10 patients for 2 weeks. Their results support our results. They explained five mechanisms that how Fibrates make plasma cholesterol levels at normal range:

1. By induction of lipoprotein lipolysis

2. By induction of hepatic fatty acid (FA) uptake and reduction of hepatic triglyceride production.

3. By increased removal of LDL particles.

4. By reduction in neutral lipid (cholesteryl ester and triglyceride) exchange between VLDL and HDL may result from decreased plasma levels of triglyceride rich lipoproteins (TRL).

5. By increase in HDL production and stimulation of reverse cholesterol transport.

Our results do not match with results of study conducted by Beghana JJ et al. [19], who proved that LDL reduction by fenofibrate is not significant if used even for three months. Reason for this contrast may be due to lesser dose of Fenofibrate ie; $20 \mathrm{mg}$ once daily for three months. In their results LDL cholesterol reduction was only $18,53 \mathrm{mg} / \mathrm{dl}$. Research conducted by Turtesov T et al. [20] stated that Fenofibrate enhances lipolysis and causes elimination of TG-rich lipoproteins from systemic circulation. This mechanism is due to activation of lipoprotein lipase. Jatoi KA et al. [21], Mastoi SM et al. [22] stated that Fenofibrates also synthesis of apoprotein C-III which is responsible for inhibition of lipoprotein lipase activity.

LDL-cholesterol values before and after treatment with Nigella sativa, Fenofibrate $\mathbf{4 0} \mathbf{m g}$ and placebo with their $\mathrm{p}$-values

\begin{tabular}{|l|c|c|c|c|}
\hline \multicolumn{1}{|c|}{ Drug } & At day-0 & At day-60 & Change in $\mathrm{mg} / \mathrm{dl}$ & $p$-values \\
\hline Kalonji group & $191,14 \pm 3,45$ & $159,40 \pm 2,98$ & 31,7 & $<0,001$ \\
\hline Fibrate group & $197,77 \pm 3,91$ & $159,62 \pm 2,20$ & 38,2 & $<0,001$ \\
\hline Placebo group & $163,10 \pm 1,45$ & $159,40 \pm 1,77$ & 3,7 & $>0,05$ \\
\hline
\end{tabular}

Key: All parameters are measured in $\mathrm{mg} / \mathrm{dl} ; p$-value $<0,01$ stands for significant change; $p$-value $>0,05$ stands for non-significant change. 
Transparency of the study. The study did not have sponsorship. The authors are solely responsible for the provision of the final version of the manuscript for publication.

Declaration of financial or other relationships. All authors participated in the conception and design of the study and in the writing of the manuscript. The final version of the manuscript was approved by all the authors. The authors did not receive a fee for the study.

\section{REFERENCES}

1. Morihana HH, Kostapanos MS, Liamis GL, Milionis HJ, Elisaf MS. Fibrates are used in all hyperlipidemic patients but be aware about its SEs. Lipid Pharmacol. 2014; 8: 112-131.

2. Suwa L, Wolfe $\mathrm{K}, \mathrm{Wu} \mathrm{X}$, Liu RH. Antioxidant activity of Nigela sativa. J Food Chem. 2013; 5: 122-128.

3. Maqbool YT, Uddin SN. Kalwanji affects plasma lipids: How? Ir J Lipids. 2014; 4 (4): 222-227.

4. Mahmud FR, Mahmud ZA, Bachar SC, Qais N. Antihyperlipidemic activity of herbal agent NS. Pharm Exp Med. 2014; 11: 267-268.

5. Fateh MA, Ahmed KA, Muniandy S, Ismail IS. Role of $\mathrm{N} \varepsilon$-(carboxymethyl) lysine in the development of ischemic heart disease in type 2 diabetes mellitus. J Clin Biochem Nutr. 2013; 43: 197-200.

6. Moraka L, Scharnagl H, Nauck M, Wieland H, Marz W. Fenofibrates are safe drugs to treat dyslipidemia? Clin Chem Lab Med. 2014; 40: 526-528.

7. Foorah SK, Asaduzzaman Kh, Chen H-Ch, Mousumi T, Zhang D-Zh. How do Fenofibrate lower blood lipids in human population: L MOA. J Ir Med. 2014; 10 (5): 326-327.

8. Jahad KI, Assayed ME. Radioprotective effects of black seed (Nigella sativa) oil against hemopoietic damage and immunosuppression in gamma-irradiated rats. Immunopharmacol Immunotoxicol. 2014; 34: 484-485.

9. Maqawat K, Yusuf M, Begum J, Hoque N, Chowdhury JU. Nigella sativa for asthma and lipids treatment. J Med Sc. 2013; 12 (7): 334-339.
10. Gurahav UT, Genwich UY, Oram JF, Lawn RM. ABCA1. Coronary artery disease is major cause of mortality in the world. Journal of Lipid research. 2014; 44 (8): 13071309.

11. Lapella D, Okamoto $H$, Kamatani N. Dyslipidemia: Successful treatment with Fenofibrate. Annals of the rheumatic diseases. 2013; 67 (13): 1509-1510.

12. Khuve J, Ali $S$, Al-Elyani F. CAD is big problem but its solution is easy, just prevent hyperlipidemia. J Sci Med. 2013; 25: 1239-1241.

13. Furkhan HY, Hossain MA, Tsujita M, Gonzalez FJ, Yokoyama S. How heart diseases are affecting human population? Journal of cardiovascular pharmacology. 2013; 51 (8): 1258-1259

14. Moghaba GT, Abdel-Aal ESM, Attia RS. Normal lipids: Healthy heart. Alex Sci Exch. 2013; 15: 583-590.

15. Summat BS, Zeggwagh NA, Moufid A, Khaldi A, Michel JB, Eddouks M. Cardiovascular effects of Nigella sativa aqueous extract. Circulation. 2013; 9 (1): 134-136.

16. Malaqa FG, Han SH, Quon MJ, Koh KK. Use of Nigella sativa in Hyperlipidemia. Clinical Pharmacology. 2013; 47 (7): 1170-1172

17. Gurfatv JH, Mohalee KI, Dehkordi FR, Kamkhah AF. Antihyperlipidemic effects of Nigella sativa seed extract in patients with primary Hyperlipidemia. Fundamental and Clinical Pharmacology. 2014; 84 (7): 1302-1303.

18. Sangatt U, Vuorio A, Kuoppala J, Kovanen PT, Humphries SE, Strandberg T, Tonstad S, Gylling H. Fibrates for familial hypersholesterolemia. Cochrane Database of Systematic Reviews. 2014; 10 (2): 222-224.

19. Beghanah JJ, Dellavalle RP, Nicholas MK, Schilling LM. Role of Fibrates in hypercholesterolemia. American journal of therapeutics. 2014; 112 (1): 403-408.

20. Turtesov T, Dasgupta S, Roy A, Jana M, Hartley DM, Pahan K. Gemfibrozil reduces risk of coronary artery disease. Lipid Pharmacology. 2014; 73 (1): 1018-1023.

21. Jatoi KA, Ghulam MM, Abdul QA. MOA of fibrates. As Jou Med Health Sc. 2012; 2 (7): 110-117.

22. Mastoi SM, Yusafzai KN, Shoro GA, Lakho RL. Dyslipidemia and its cure. AJMS. 2013; 7 (4): 334-337. 